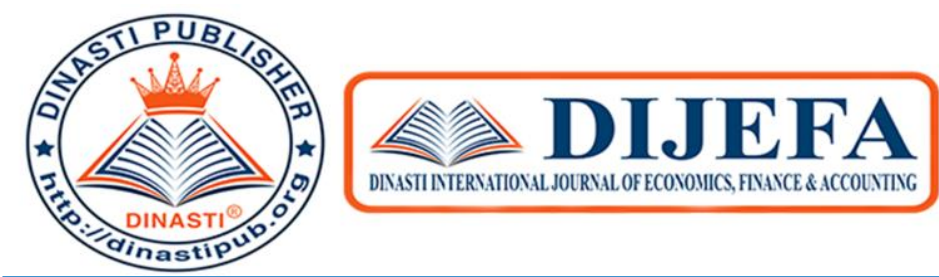

+6281387654578 (9)

+6281387654578 (Q)

https://dinastipub.org/DIJEFA (2)

dinasti-info@gmail.com G.

\title{
BANKRUPTCY PREDICTION ANALYSIS USING THE ZMIJEWSKI MODEL (X- SCORE) AND THE ALTMAN MODEL (Z-SCORE)
}

\section{Viciwati}

Universitas Mercu Buana, Indonesia,

ARTICLE INFORMATION

Received: $29^{\text {th }}$ September 2020

Revised: $14^{\text {th }}$ October 2020

Issued: $22^{\text {nd }}$ November 2020

Corresponding author: first author

E-mail:

viciwati@mercubuana.ac.id

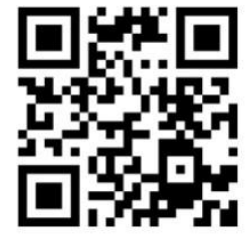

DOI: $10.38035 / D I J E F A$
Abstract: This study aims to identify and analyze the accurate models of Financial Distress in retail companies listed on the Indonesian Stock Exchange in 2014-2018 using the Zmijewski (X-Score) and Altman (Z-Score) Model. The sample used is 70. This study uses secondary data from the 2014-2018 annual financial reports. This study tested the hypothesis using the normality test and the Kruskal Wallis test or the difference test using SPSS version 26. The results of this study indicate that the Zmijewski (X-Score) model is the model that has the highest accuracy rate in predicting bankruptcy with an accuracy rate of $90 \%$.

Keywords: Bankruptcy Prediction, Accuracy, Zmijewski, Altman.

\section{INTRODUCTION}

Changing economic conditions will certainly have an impact on economic sectors, particularly the trade sector. Retail business is a business activity that includes selling goods or services directly to end consumers which are used for personal, family, or household needs (Utami, 2008).

With the existence of an online store, it hurts offline stores, if before the consumers shop for their needs at offline stores, now consumers have started to switch to online shop transactions. This is what causes people's attractiveness to offline stores or commonly called retailers to decline and not develop. The general chairman of the Indonesian Employers' Association (Apindo) Hariyadi B. Sukamdani said the continued sluggish trade performance was a reflection of weakening purchasing power or declining household consumption of Indonesians.

Data on Indonesia's trade balance for 2013-2019, 2013 experienced a deficit of US \$ -4.08 billion, in 2014 again experienced a deficit of US \$ -2.2 billion, while 2015 to 2017 experienced a surplus, and experienced another deficit in 2018 and 2019 the deficit was the US \$ -3.2 billion. One of the retail trading companies that were affected, namely the company 
PT HERO Supermarket Tbk (HERO) throughout 2018 HERO has closed 26 outlets. On July 28, 2019, HERO closed 6 outlets under the Giant brand. According to HERO director, Hadrianus Wahyu Trikusumo, food retail in Indonesia has experienced increased competition in recent years due to changes in consumer spending patterns. Deputy Chairperson of Aprindo Tutum Rahanta of the Indonesian Retail Entrepreneurs Association (Aprindo) revealed and assessed that efficiency through closure is a natural thing in the retail industry scope to maintain the company's business.

The purpose of establishing a company in the long term is to maximize the value of the company through increasing the prosperity of the owner and shareholders, the higher the value of the company, the more prosperous the owner and shareholders are. The ability of a company to be able to maintain its business continuity to compete is determined by the company's performance. Some companies that cannot maintain their performance will lose to other companies that are more competitive. If the company cannot maintain and manage properly, it will result in a decrease in financial performance and even lead to bankruptcy. Bankruptcy, or the owner of another name bankruptcy, is the risk of business failure that will occur when the fair market value of the assets is less than the company's liabilities or debts (Sunarto, 2006). Bankruptcy is a situation where the company is no longer able to fulfill its obligations because the company has experienced a lack of funds to run its business so that the purpose of establishing the company cannot be achieved. Bankruptcy analysis is very important because it can assess indications of company bankruptcy, whether a company is threatened with bankruptcy or not. Information regarding finances is used by people who are at the same time as people who are at an early age. So that the damage and even the parties to the worst conditions are still very poor (Dirman Angela, 2020).

The research that has been conducted (Huda, Paramita, and Amboningtyas, 2018) is entitled Financial Distress Analysis using Altman, Springate, and Zmijewski Models in Retail Companies Listed on the IDX 2013-2017. The results of his research, namely according to the Altman model, 4 companies were experiencing financial distress, the Springate and Zmijewski models, 2 companies were experiencing financial distress. Zmijewski's model is the model with the highest level of accuracy and has the lowest error rate.

There are differences in the results of other research conducted (Anggraeni and Sitorus, 2019) with the title Comparative Analysis of the Potential Bankruptcy of Retail Companies in Indonesia with the Altman Z-Score, Springate, and Zmijewski models. The results showed that eleven companies experienced bankruptcy for the period 2012-2017 based on the Altman Z-Score, Springate, and Zmijewski models. The eleven companies, namely: CENT, GOLD, HERO, KOIN, LPPF, MAPI, MIDI, MPPA, RIMO, SKYB, and TRIO. Then, it is known that there are significant differences in results between the results of these studies.

\section{LITERATURE REVIEW}




\section{Financial Statements}

Definition of Financial Statements

In the opinion of Hery (2016). "Financial reports are basically the result of an accounting process that can be used as a tool to communicate financial data or company activities to interested parties". According to the opinion of the Indonesian Accounting Association (IAI) (2009) "financial reports are part of the financial reporting process which includes balance sheets, income statements, changes in financial position reports, notes and other reports as well as explanatory material that is an integral part of financial statements".

\section{Bankruptcy}

Definition of bankruptcy

Sembiring (2016) suggests that bankruptcy is a failure that occurs within a company when the company experiences an economic failure (economic distressed) and financial failure (financial distressed). Economic failure (economic distressed), which means that the company's revenue is no longer able to cover its costs or that its profit rate is lower than the cost of capital. Financial failure (financial distressed) means that the company fails to fulfill one or more conditions in its debt provisions (technical default), and the company is unable to fulfill its obligations at a predetermined time (technical insolvency).

\section{Bankruptcy prediction}

Bankruptcy can be predicted long before the company goes bankrupt. Therefore, bankruptcy cannot be detected in a short time. However, the time used is usually two to five years as a tolerance limit for decreased performance to detect possible company bankruptcy (Triharyanti, 2018 in Bimawiratma 2016).

\section{Previous Research}

Parquinda, and Azizah (2019) Analysis of the Use of the Grover (G-Score), Fulmer (HScore), Springate (S-Score), Zmijewski (X-Score) and Altman (Z-Score) Models as Predictors of Bankruptcy (Study on Textile and Garment Companies which are listed on the Indonesia Stock Exchange (IDX) for the 2015-2017 period), the results of this study are that in the Grover model, companies that are predicted to go bankrupt in 2015 are 4 companies, in 2016 and 2017, namely 3 companies. In the Fulmer model, the companies that are predicted to go bankrupt in 2015 and 2016 are 2 companies, in 2017, 3 companies. In the Springate model, companies that are predicted to go bankrupt in 2015 and 2016 are 9 companies, in 2017 there are 10 companies. In the Altman model, the companies that are predicted to go bankrupt in 2015, 2016 and 2017 are 8 companies. The highest accuracy model, the Fulmer (H-Score) model, has an accuracy rate of $80.56 \%$.

Barry (2019) Prediction of Financial Distress Model (Bankruptcy) in Stock Exchange Retail Companies with the Altman and Springate Indonesia Models for the 2012-2016 Period. The results of this study are that the companies OKAS, KONI, INTA, and RIMO are predicted to experience financial distress or have the potential to go bankrupt.

Huda, Paramita, and Amboningtyas (2018) Analysis of Financial Distress Using the Altman, Springate and Zmijewski Models for Retail Companies Listed on the IDX 2013-2017. According to the Altman model, there are 4 companies that experience financial distress, the 
Springate and Zmijewski models, there are 2 companies that experience financial distress. Zmijewski's model is the model with the highest level of accuracy and has the lowest error rate.

Adamko, and Chutka (2019) Company bankruptcy and its prediction in conditions of globalization. The accuracy rate of the Fulmer model is up to $98 \%$. By analyzing 60 companies, half of the companies were successful and half of them indicated financial problems. Only predicts bankruptcy, does not test model accuracy.

Ditasari, Triyono, and Sasongko (2019). There are differences in clarifying financial difficulties between the Altman and Springate models, Altman and Grover, Altman and Zmijewski, Springate and Grover, Springate, and Zmijewski models. Meanwhile, there is no difference in the clarification of financial difficulties between the Grover and Zmijewski models. Comparison of Altman, Springate, Zmijewski, and Grover Models in Predicting Financial Distress on Companies of Jakarta Islamic Index (JII) on 2013-2017.

\section{RESEARCH METHODS}

This study uses secondary data obtained from retail company financial statement data for 2014-2018 from www.idx.id. This study is intended to analyze the comparison of the prediction of Finacial Distress with the Zimjewski (X-core) model and the Altman (Z-Score) model of the 2015 - 2017 study and which is the best model used in predicting financial distress in retail companies.

\section{Zmijewski model}

Zmijewski used a probit model to predict bankruptcy, Elviani, Simbolon, Riana, Khairani, Dewi, and Fauzi (2020). An empirical test is conducted on a financial distress model that requires a sample of companies that experience financial pressure and companies that do not. The equation for the function of the Zmijewski model is as follows:

$\mathrm{X}$-Score $=-4.3-4.5 \mathrm{X} 1+5.7 \mathrm{X} 2-0.004 \mathrm{X} 3$

Where:

$\mathrm{X} 1$ = Net Income / Total Assets

$\mathrm{X} 2=$ Total Liabilities $/$ Total Assets

X3 = Current Assets / Current Liabilities

Zmijewski model categories, namely:

a. If $X>0$ the company is predicted to go bankrupt,

b. If $X<0$ the company is predicted not to go bankrupt.

\section{Altman model}

Fitriyanti, and Irni (2015) in Sari, (2018) suggest that the Altman model bankruptcy analysis is one of the tools used to predict the level of bankruptcy of a company by calculating the value of several ratios and then entering it into a discriminant equation. Altman's model discriminant equations are as follows (Hanafi and Halim 2009):

$\mathrm{Z}$-Score $=1,2 \mathrm{X} 1+1,4 \mathrm{X} 2+3,3 \mathrm{X} 3+0,6 \mathrm{X} 4+1,0 \mathrm{X} 5$

Where:

X1 = Working Capital / Total Asset

$\mathrm{X} 2$ = Retained Earnings $/$ Total Asset

X3 = EBIT $/$ Total Asset

X4 = Market Value of Equity / Book Value of Total Debt 
X5 = Sales / Total Asset

Altman model categories, namely:

a. If $\mathrm{Z}<1.88$ the company is predicted to go bankrupt,

b. If 1.81-2.99 companies are predicted to have financial problems, and are prone to bankruptcy.

c. If $\mathrm{Z}>2.99$ the company is predicted not to go bankrupt.

Accuracy level, type I error and type II error

a. Level of accuracy

According to Christine (2013), the accuracy rate shows the percentage of the model in predicting the company's condition correctly based on the entire sample. The following is a formula for calculating the level of accuracy and type of error:

Tingkat Akurasi $=$ number of predistions is correct $\times 100 \%$

Number of samples

In addition to the level of accuracy, this study also analyzes the percentage of error types. According to Prihadi (2010), each model always has the possibility of incorrect predictions and a difference in the level of $100 \%$ accuracy. The prediction tool is said to be true if the predicted and actual are the same, while an error occurs when the predicted and actual ones are not the same. Errors arising from prediction tools consist of:

b. Type I error

The error where the prediction tool states that it is not bankrupt turns out to be actually bankrupt.

c. Type II error

The error where the prediction tool declares bankruptcy is not actually bankrupt. The error type rate can be calculated as follows:

$$
\begin{aligned}
\text { Tipe } I=\frac{\text { number of corrects type I }}{\text { Number of Sample }} \times 100 \% \\
\text { Tipe II }=\frac{\text { Number of correct type II }}{\text { Number of sample }} \times 100 \%
\end{aligned}
$$

Data analysis technique

In testing this hypothesis there are 2 possibilities, namely:

1. Normal Data

The data is said to be normal, that is, if the analyzed data is normally distributed, the test used is

a. Data Normality Test

The data model meets the normality assumption based on decision making if the probability value is $>0.05$ and vice versa, if the probability value is $<0.05$ then the regression model does not meet the normality assumption of testing using the Kolmogorov Smirnov test.

b. Homogeneity Test

The homogeneity test aims "to test whether the variable data model has a homogeneous distribution or not. The data model fulfills the homogeneity assumption based on decision making, if the probability value is> 0.05 and vice 
versa, if the probability value is $<0.05$, the regression model does not meet the homogeneity assumption.

c. Hypothesis test

Different Test (one-way Anova)

The One Way Anova test or Analysis of Variance is used to test more than two samples, in this study the One Way Anova test is used to determine the comparison of the Ohlson, Fulmer, CA-Score, and Zavgren models in predicting financial distress in retail companies in Indonesia. $\mathrm{F}$ test was conducted to compare $F$ count with $F$ table at a significant level of $5 \%(0.05)$ ". If $F$ count $>F$ table, the independent variable can explain the bound, meaning that there is an influence between the prediction model and the prediction of bankruptcy.

1) If $F$ count $<F$ table or $p$ value $>a$ is said to be insignificant, and the research hypothesis is rejected.

2) If $F$ count $>F$ table or $p$-value $<a$ is said to be insignificant, and the research hypothesis is accepted.

The requirements of the hypothesis test in this study are

$\mathrm{HO}=$ the four models mean there is no difference.

$\mathrm{H} 1=$ the four models mean there are differences.

2. Data Abnormal

In the hypothesis test, the data were not normally distributed, the test used was the Kruskal Wallis test. In the Kruskal Wallis test, the conditions are:

$\mathrm{H} 0=$ The four models are identical (the four financial distress models are not significantly different.

$\mathrm{H} 1=$ The four financial distress models are significantly different.

The significance level of the difference in the Kruskal Wallis test is if Asymp. Sig below 0.05 , there is a difference, if above 0.05 there is no difference.

Data Abnormal

In the hypothesis test, the data were not normally distributed, the test used was the Kruskal Wallis test. In the Kruskal Wallis test, the conditions are:

$\mathrm{H} 0=$ The four models are identical (the four financial distress models are not significantly different significant.

$\mathrm{H} 1=$ The four financial distress models significantly different.

The significance level of the difference in the Kruskal Wallis test is if Asymp. Sig below 0.05 , there is a difference, if above 0.05 there is no difference 


\section{FINDINGS AND DISCUSSION}

Table 1. Calculations using the Zmijewski model show the potential category of bankruptcy

\begin{tabular}{|l|l|l|}
\hline Company Code & Year & X-Score \\
\hline AMRT & 2015 & 0.876917573 \\
\hline KOIN & 2015 & 0.276553186 \\
\hline KOIN & 2015 & 0.419527894 \\
\hline KOIN & 2015 & 0.628741317 \\
\hline KOIN & 2015 & 0.761452416 \\
\hline MPPA & 2015 & 1.195223645 \\
\hline MPPA & 2015 & 0.874907041 \\
\hline
\end{tabular}

Source:Processed Data (2020)

Table 2. Calculations using the Altman model show the Gray category

\begin{tabular}{|l|l|l|}
\hline Company Code & Year & Z-Score \\
\hline MPPA & 2017 & 1.464233582 \\
\hline MPPA & 2018 & 1.539162699 \\
\hline
\end{tabular}

Source:Processed Data (2020)

Table 3. Calculations using the Altman model show the Gray category

\begin{tabular}{|l|l|l|}
\hline Company Code & Year & Z-Score \\
\hline CSAP & 2014 & 2.716305392 \\
\hline CSAP & 2015 & 2.518482003 \\
\hline CSAP & 2016 & 2.571319184 \\
\hline CSAP & 2017 & 2.434726035 \\
\hline CSAP & 2018 & 2.533744011 \\
\hline HERO & 2018 & 2.821026397 \\
\hline KOIN & 2014 & 2.860592787 \\
\hline KOIN & 2015 & 2.539736025 \\
\hline KOIN & 2016 & 2.36779042 \\
\hline KOIN & 2017 & 2.362251911 \\
\hline KOIN & 2018 & 2.198399686 \\
\hline MAPI & 2014 & 2.246686516 \\
\hline MAPI & 2016 & 2.920160676 \\
\hline MAPI & 2017 & 2.591912113 \\
\hline MAPI & 2018 & 2.880949684 \\
\hline MPPA & 2014 & 2.90306169 \\
\hline SOurceProcsed Dat &
\end{tabular}

Source:Processed Data (2020)

A. Hiphothesys Test 
Table 4. Result of Normality test

\begin{tabular}{|c|c|c|c|}
\hline & & ZMIJEWSKI & ALTMAN \\
\hline $\mathrm{N}$ & & 14 & 14 \\
\hline \multirow[t]{2}{*}{ Normal Parameters ${ }^{\text {a.b }}$} & Mean & -1.6548843 & 4.7689407 \\
\hline & Std. Deviation & 1.37759315 & 2.10218653 \\
\hline \multirow[t]{3}{*}{ Most Extreme Differences } & Absolute & .120 & .246 \\
\hline & Positive & .089 & .246 \\
\hline & Negative & -.120 & -.164 \\
\hline Test Statistic & & .120 & .246 \\
\hline Asymp. Sig. (2-tailed) & & $.200^{\mathrm{c}}$ & $.022^{\mathrm{c}}$ \\
\hline
\end{tabular}

Source:Processed Data (2020)

In table 4. the results of the normality test using the One-Sample Kolmogorov Smirnov test, the sig value is more than 0.05 , which means that the data is normally distributed, namely the Zmijewski model is 0.200, while the Altman model has an abnormally distributed value of 0.022 .

Because the data were not normally distributed, a different test was performed using the Kruskal Wallis test. The Kruskal Wallis test is an alternative test for the One Way ANOVA test. Because the data were not normally distributed, the One Way ANOVA test was discontinued, so it used the Kruskal Wallis test. The results of the Kruskal Wallis test are shown in Table 5.

Table 5. Result of Kruskal wallis test

Ranks

\begin{tabular}{|c|c|c|c|}
\hline & Model & $\mathrm{N}$ & $\begin{array}{l}\text { Mean } \\
\text { Rank }\end{array}$ \\
\hline \multirow[t]{3}{*}{ Prediksi } & ZMIJEWSKI & 70 & 41.01 \\
\hline & ALTMAN & 70 & 241.97 \\
\hline & Total & 140 & \\
\hline
\end{tabular}

Test Statistics ${ }^{\text {a.b }}$

\begin{tabular}{lr} 
& Prediction \\
\hline Kruskal-Wallis & 224.807 \\
H & 3 \\
df & .000 \\
Asymp. Sig. & \\
\hline \multicolumn{2}{l}{ Source:Processed Data (2020) }
\end{tabular}


In Figure 5 the results of the Kruskal Wallis test, the sig value shows the value of 0.000 , which is the sig value $<0.05$, which means that there is a significant difference between the two bankruptcy prediction models.

1. Model Zmijewski

\section{Table 6. Results of the Level of Accuracy and Errors for Type I and II Zmijewski Models}

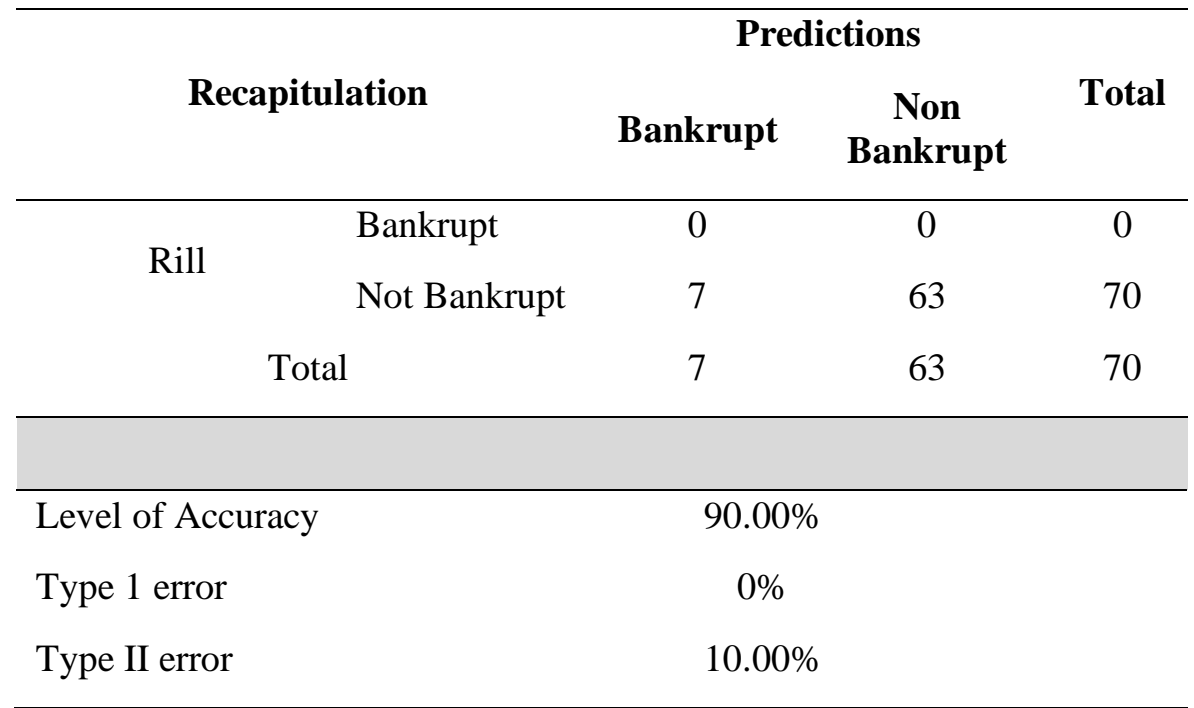

Source:Processed Data (2020)

Level of Accuracy = the number of predictions is correct $\times 100 \%$

Number of samples

$$
\begin{aligned}
= & 63 \times 100 \% \\
& 70 \\
= & 90 \%
\end{aligned}
$$

Type I error

$$
\begin{aligned}
& =\frac{\text { Number of Type I errors }}{\text { Number of samples }} \times 100 \% \\
& =0 \times 100 \% \\
& \quad 70 \\
& =0 \%
\end{aligned}
$$

Type II error $\quad=\underline{\text { Number of type II errors }} \times 100 \%$

$$
\text { Number of samples }
$$

$$
\begin{aligned}
& =7 \times 100 \% \\
& =10 \\
& =10 \%
\end{aligned}
$$

It can be seen in Table 4:11 that the calculation results for the accuracy of the Zmijewski model are $90 \%$, for type I errors are obtained $0 \%$, while for type II errors are obtained $10 \%$. 
2. Model Altman

Table 7. Results of the Level of Accuracy and Errors for Type I and II Altman Models Predictions

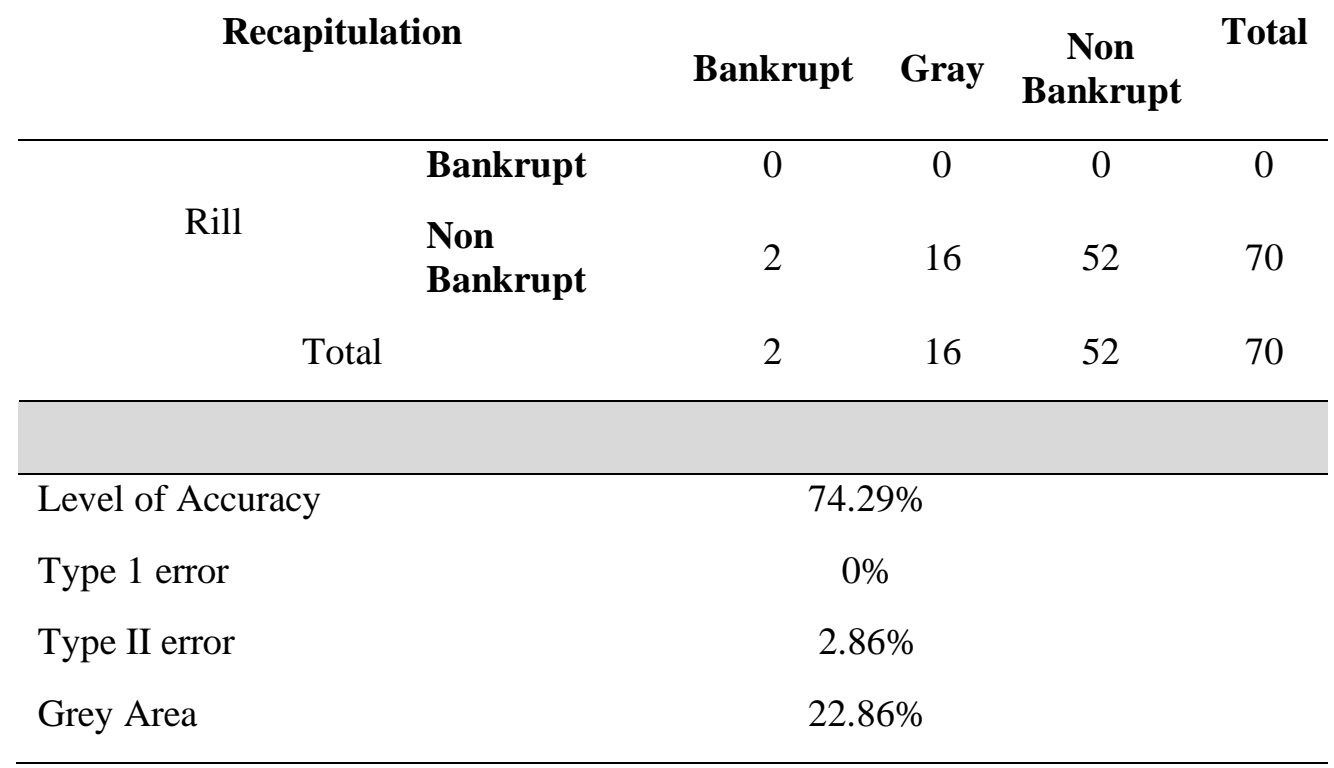

Source:Processed Data (2020)

Level of Accuracy = the number of predictions is correct $\times 100 \%$

$$
\begin{aligned}
& \text { Number of samples } \\
= & 52 \times 100 \% \\
& 70 \\
= & 74.29 \%
\end{aligned}
$$

Type I error

$$
\begin{aligned}
& =\frac{\text { Number of Type I errors }}{\text { Number of samples }} \times 100 \% \\
& =0 \times 100 \% \\
& \quad 70 \\
& =0 \%
\end{aligned}
$$

Type II error

$$
=\underline{\text { Number of Type II errors }} \times 100 \%
$$$$
\text { Number of samples }
$$

$$
\begin{aligned}
& =2 \times 100 \% \\
& 70 \\
& =2.86 \%
\end{aligned}
$$

Grey Area

$$
\begin{aligned}
= & \frac{\text { Number of Grey Area }}{\text { Number of samples }} \\
= & 16 \times 100 \% \\
& 70 \\
= & 22.86 \%
\end{aligned}
$$

It can be seen in Table 7 that the results of the calculation of the accuracy of the Altman model are $74.29 \%$, for type I error is $0 \%$, type II error is $2.86 \%$, while the gray area is obtained $22.86 \%$. 
In Zmijewski's model, there are three companies predicted to go bankrupt, namely PT Sumber Alfaria Trijaya Tbk (AMRT), PT Kokoh Inti Arebama Tbk (KOIN), PT Matahari Putra Prima Tbk (MPPA).

The Altman model that is predicted to go bankrupt is PT Matahari Putra Prima Tbk (MPPA), while it is predicted to be in the gray category of PT Catur Sentosa Adiprana Tbk (CSAP), PT Hero Supermarket Tbk (HERO), PT Kokoh Inti Arebama Tbk (KOIN), PT Mitra Adiperkasa Tbk (MAPI), PT Matahari Putra Prima Tbk (MPPA).

\section{CONCLUSION AND SUGESTION}

\section{Conclusion}

1. The prediction results of bankruptcy using the Zmijewski (X-Score) model, namely that there are three companies predicted to go bankrupt, namely PT Sumber Alfaria Trijaya Tbk in 2015, PT Kokoh Inti Arebama Tbk in five consecutive years 2014 to 2018 are predicted to experience bankruptcy, PT Matahari Putra Prima Tbk in 2017 and 2018 is predicted to go bankrupt. The results of bankruptcy prediction using the Altman model, namely PT Matahari Putra Prima Tbk in 2017 and 2018 are predicted to be bankrupt while those predicted in the gray zone will have five companies, namely PT Catur Sentosa Adiprana Tbk for five consecutive years 2014 to 2018, PT Hero Supermarket Tbk In 2018, PT Kokoh Inti Arebama Tbk for five consecutive years 2014 to 2018, PT Mitra Adiperkasa Tbk in 2014, 2016, until 2018, and PT Matahari Putra Prima Tbk in 2016 are predicted to fall into a gray zone. There are seven companies predicted to experience bankruptcy from the four models, namely ECII, AMRT, CSAP, HERO, KOIN, MAPI, and MPPA.

2. Zmijewski model (X-Score) is the most accurate bankruptcy prediction model compared to Altman model (Z-Score). The accuracy value of the Zmijewski model (X-Score) is $90 \%$ with a type I error of $0 \%$, while a type II error is $10 \%$.

\section{Suggestion}

1. There are limitations in this study, namely that it only uses two bankruptcy prediction models and the period for which it is carried out is only five years. Therefore, the researchers suggest that further research can use other models such as the Sringate model, Ohlson, Fulmer, Zavgren, CA-Score, and other bankruptcy prediction models. And extend the research period so that the sample used is also increasing.

2. For companies, to be able to consider the results of the Zmijewski model to minimize or avoid the risk of bankruptcy.

\section{REFERENCE}

Adamko. P \& Chutka, J. (2020). Company bankruptcy and its prediction in conditions of globalization. SHS Web of Conferences 74, 05002.

Barry, H. (2019). Prediksi Model Financial Distress (Kebangkrutan) pada Perusahaan Ritel Bursa Efek dengan Model Altman dan Springate Indonesia Periode 2012-2016. Account: Vol. 6 No.1. 
Bimawiratma, Partisius Gerdian. 2016. Analisis Akurasi Metode Altman, Grover, Springate dan Zmijewski Dalam Memprediksi Perusahaan Delisting (Studi Empiris Pada Perusahaan Manufaktur di Bursa Efek Indonesia Periode 2009-2013).

Christianti, Ari. 2013. Akurasi Prediksi Financial Distress : Perbandingan Model Altman dan Ohlson. Jurnal Ekonomi dan Bisnis Vol. 7 No. 2, hlm. 77-89. ISSN : 1978-3116.

Dirman, Angela. 2020. Financial Distress: The Impacts Of Profitability, Liquidity, Leverage, Firm Size, And Free Cash Flow. International Journal of Business, Economics and Law, Vol. 22, Issue 1.

Ditasari, R. A., Triyono, Dr. \& Sasongko, Dr. N. (2019). Comparison of Altman, Springate, Zmijewski and Grover Models in Predicting Financial Ditress on Companies of Jakarta Islamic Index (JII) on 2013-2017. International Summit on Science Technology and Humanity.

Elviani, S., Simbolon, R., Riana, Z., Khairani, F., Dewi, S. P., \& Fauzi. (2020). The Accuracy of the Altman, Ohlson, Springate, and Zmijewski Model in bankcruptcy Predicting Trade Sector Companies in Indonesia. Budapest International Research and Institute-Journal (BIRCIJournal). Vol. 3. No.1.

Fitriyanti, Erlyn Dyah dan Irni Yunitas. 2015. Penggunaan Model Zmijewski, Altman Z-Score dan Model Springate Untuk Memprediksi Kebangkrutan Pada Sektor dan Model Springate Untuk Memprediksi Kebangkrutan Pada Sektor Property dan Real Estate yang Terdaftar di BEI Tahun 2011-2013. Jurnal Universitas Telkom.

Hanafi, Mamduh M dan Abdul Halim. 2009. Analisis Laporan Keuangan. Edisi Keempat Cetakan Pertama. UPP STIM YKPN, Yogyakarta.

Hery. 2016. Analisis Kinerja Manajemen. Jakarta: Grasindo.

Hery, SE., M.Si. 2005. ”Analisis Laporan Keuangan Pendekatan Rasio

Keuangan”. Cetakan pertama CAPS. Yogyakarta.

Huda, E. N, Paramita, P. D., \& Amboningtyas, SE, MM. D. A. (2018). Analisis Financial Distress dengan Menggunakan Model Altman, Springate dan Zmijewski pada Perusahaan Retail yang Terdaftar di BEI Tahun 2013-2017. Fakultas Ekonomi Universitas Pandanaran.

Ikatan Akuntan Indonesia. 2007. Standar Akuntasnu Keuangan. Jakarta: Salemba Empat

Ikatan Akuntan Indonesia. 2009. Standar Akuntansi Keuangan Entitas Tanpa

Akuntabilitas Publik.Ikatan Akuntan Indonesia, Jakarta.

Parquinda, L. \& Azizah, D. F (2019). Analisis Penggunaan Model Grover (G-Score), Fulmer (HScore), Springate (S-Score), Zmijewski (X-Score) dan Altman (Z-Score) Sebagai Prediktor Kebangkrutan (Studi pada Perusahaan Tekstil dan Garmen yang Listing di Bursa Efek Indonesia (BEI) Periode 2015-2017), Disertasi Fakultas. Jurnal Administrasi Bisnis (JAB). Vol. 72 No. 1.

Prihadi, Toto. 2010. Analisis Laporan Keuangan: Teori dan Aplikasi. PPM,

Jakarta 
Sembiring, Etti Ernita. 2016. Analisis Keakuratan Model Ohlson dalam Akuntansi Keuangan dan Bisnis. Vol. 9 Hlm. 1-9

Utami, Christina Widya. 2006. Manajemen Ritel Strategi dan Implementasi Ritel Modern, Salemba Empat. Jakarta. Utami, Nunik Setiyo. 2018. Analisa Kinerja 